\title{
Vasopressin and oxytocin receptors (version 2019.4) in the IUPHAR/BPS Guide to Pharmacology Database
}

\author{
Daniel Bichet ${ }^{1}$, Michel Bouvier ${ }^{2}$, Bice Chini ${ }^{3}$, Gerald Gimpl ${ }^{4}$, Gilles Guillon ${ }^{5}$, Tadashi Kimura ${ }^{6}$, Mark Knepper ${ }^{7}$, \\ Stephen Lolait ${ }^{8}$, Maurice Manning ${ }^{9}$, Bernard Mouillac ${ }^{10}$, Anne-Marie O'Carroll ${ }^{8}$, Claudine Serradeil-Le Gal ${ }^{11}$, \\ Melvyn Soloff ${ }^{12}$, Joseph G. Verbalis ${ }^{13}$, Mark Wheatley ${ }^{14}$ and Hans H. Zingg ${ }^{15}$ \\ 1. University of North Carolina, USA \\ 2. Université de Montréal, Canada \\ 3. CNR Institute of Neuroscience, Italy \\ 4. Johannes Gutenberg-Universität, Germany \\ 5. Institut de Génomique Fonctionnelle, France \\ 6. Osaka University, Japan \\ 7. National Institutes of Health, USA \\ 8. University of Bristol, UK \\ 9. University of Toledo College of Medicine, USA \\ 10. Université de Montpellier, France \\ 11. Sanofi Synthelabo Recherche, France \\ 12. University of Texas, USA \\ 13. Georgetown University Medical Center, USA \\ 14. University of Birmingham, UK \\ 15. McGill University, Canada
}

\begin{abstract}
Vasopressin (AVP) and oxytocin (OT) receptors (nomenclature as recommended by NC-IUPHAR [92]) are activated by the endogenous cyclic nonapeptides vasopressin and oxytocin. These peptides are derived from precursors which also produce neurophysins (neurophysin I for oxytocin; neurophysin II for vasopressin). Vasopressin and oxytocin differ at only 2 amino acids (positions 3 and 8 ). There are metabolites of these neuropeptides that may be biologically active [67].
\end{abstract}

\section{Contents}

This is a citation summary for Vasopressin and oxytocin receptors in the Guide to Pharmacology database (GtoPdb). It exists purely as an adjunct to the database to facilitate the recognition of citations to and from the database by citation analyzers. Readers will almost certainly want to visit the relevant sections of the database which are given here under database links.

GtoPdb is an expert-driven guide to pharmacological targets and the substances that act on them. GtoPdb is a reference work which is most usefully represented as an on-line database. As in any publication this work should be appropriately cited, and the papers it cites should also be recognized. This document provides a citation for the relevant parts of the database, and also provides a reference list for the research cited by those 
parts.

Please note that the database version for the citations given in GtoPdb are to the most recent preceding version in which the family or its subfamilies and targets were substantially changed. The links below are to the current version. If you need to consult the cited version, rather than the most recent version, please contact the GtoPdb curators.

\section{Database links}

Vasopressin and oxytocin receptors

http://www.guidetopharmacology.org/GRAC/FamilyDisplayForward?familyld=66

Introduction to Vasopressin and oxytocin receptors

http://www.guidetopharmacology.org/GRAC/FamilyIntroductionForward?familyld=66

Receptors

$\mathrm{V}_{1 \mathrm{~A}}$ receptor

http://www.guidetopharmacology.org/GRAC/ObjectDisplayForward?objectld=366

$\mathrm{V}_{1 \mathrm{~B}}$ receptor

http://www.guidetopharmacology.org/GRAC/ObjectDisplayForward?objectld=367

$\mathrm{V}_{2}$ receptor

http://www.guidetopharmacology.org/GRAC/ObjectDisplayForward?objectld=368

OT receptor

http://www.guidetopharmacology.org/GRAC/ObjectDisplayForward?objectld=369

\section{References}

1. Adan RA, Van Leeuwen FW, Sonnemans MA, Brouns M, Hoffman G, Verbalis JG and Burbach JP. (1995) Rat oxytocin receptor in brain, pituitary, mammary gland, and uterus: partial sequence and immunocytochemical localization. Endocrinology 136: 4022-8 [PMID:7649111]

2. Ahn TG, Han SJ, Cho YS, An TH, Pak SC and Flouret G. (2004) In vivo activity of the potent oxytocin antagonist on uterine activity in the rat. In Vivo 18: 763-6 [PMID:15646817]

3. Akerlund M, Bossmar T, Brouard R, Kostrzewska A, Laudanski T, Lemancewicz A, Serradeil-Le Gal C and Steinwall M. (1999) Receptor binding of oxytocin and vasopressin antagonists and inhibitory effects on isolated myometrium from preterm and term pregnant women. Br J Obstet Gynaecol 106: 1047-53 [PMID:10519430]

4. Akerlund M, Carlsson AM, Melin P and Trojnar J. (1985) The effect on the human uterus of two newly developed competitive inhibitors of oxytocin and vasopressin. Acta Obstet Gynecol Scand 64: 499-504 [PMID:4061066]

5. Ala Y, Morin D, Mouillac B, Sabatier N, Vargas R, Cotte N, Déchaux M, Antignac C, Arthus MF and Lonergan $\mathrm{M}$ et al.. (1998) Functional studies of twelve mutant $\mathrm{V} 2$ vasopressin receptors related to nephrogenic diabetes insipidus: molecular basis of a mild clinical phenotype. J. Am. Soc. Nephrol.9: 186172 [PMID:9773787]

6. Albertazzi E, Zanchetta D, Barbier P, Faranda S, Frattini A, Vezzoni P, Procaccio M, Bettinelli A, Guzzi F and Parenti $\mathrm{M}$ et al.. (2000) Nephrogenic diabetes insipidus: functional analysis of new AVPR2 mutations identified in Italian families. J. Am. Soc. Nephrol. 11: 1033-43 [PMID:10820167]

7. Albright JD, Reich MF, Delos Santos EG, Dusza JP, Sum FW, Venkatesan AM, Coupet J, Chan PS, Ru X and Mazandarani $\mathrm{H}$ et al.. (1998) 5-Fluoro-2-methyl-N-[4-(5H-pyrrolo[2,1-c]-[1, 4]benzodiazepin-10(11H)ylcarbonyl)-3-chlorophenyl]benzamide (VPA-985): an orally active arginine vasopressin antagonist with selectivity for V2 receptors. J. Med. Chem. 41: 2442-4 [PMID:9651149]

8. Alexandrova M and Soloff MS. (1980) Oxytocin receptors and parturition. I. Control of oxytocin receptor concentration in the rat myometrium at term. Endocrinology 106: 730-5 [PMID:6243547]

9. Andrés M, Trueba M and Guillon G. (2002) Pharmacological characterization of F-180: a selective human 
V(1a) vasopressin receptor agonist of high affinity. Br. J. Pharmacol. 135: 1828-36 [PMID:11934825]

10. Antoni FA. (1986) Oxytocin receptors in rat adenohypophysis: evidence from radioligand binding studies. Endocrinology 119: 2393-5 [PMID:3021442]

11. Antoni FA. (1984) Novel ligand specificity of pituitary vasopressin receptors in the ratNeuroendocrinology 39: 186-188 [PMID:6089020]

12. Antoni FA, Holmes MC, Makara GB, Kárteszi M and László FA. (1984) Evidence that the effects of arginine-8-vasopressin (AVP) on pituitary corticotropin (ACTH) release are mediated by a novel type of receptor. Peptides 5: 519-522 [PMID:6089144]

13. Aoyagi T, Birumachi J, Hiroyama M, Fujiwara Y, Sanbe A, Yamauchi J and Tanoue A. (2007) Alteration of glucose homeostasis in V1a vasopressin receptor-deficient mice. Endocrinology 148: 2075-84 [PMID:17303660]

14. Arletti R, Benelli A and Bertolini A. (1990) Oxytocin inhibits food and fluid intake in rats.Physiol. Behav. 48 : 825-30 [PMID:2087513]

15. Atke A and Vilhardt H. (1987) Uterotonic activity and myometrial receptor affinity of 1-deamino-1-carba-2tyrosine(O-methyl)-oxytocin. Acta Endocrinol. 115: 155-60 [PMID:3035851]

16. Azzi M, Charest PG, Angers S, Rousseau G, Kohout T, Bouvier M and Piñeyro G. (2003) Beta-arrestinmediated activation of MAPK by inverse agonists reveals distinct active conformations for $G$ proteincoupled receptors. Proc. Natl. Acad. Sci. U.S.A. 100: 11406-11 [PMID:13679574]

17. Bachner-Melman R, Dina C, Zohar AH, Constantini N, Lerer E, Hoch S, Sella S, Nemanov L, Gritsenko I and Lichtenberg P et al.. (2005) AVPR1a and SLC6A4 gene polymorphisms are associated with creative dance performance. PLoS Genet. 1: e42 [PMID:16205790]

18. Baertschi AJ and Friedli M. (1985) A novel type of vasopressin receptor on anterior pituitary corticotrophs? Endocrinology 116: 499-502 [PMID:2981663]

19. Bale TL, Pedersen CA and Dorsa DM. (1995) CNS oxytocin receptor mRNA expression and regulation by gonadal steroids. Adv. Exp. Med. Biol. 395: 269-80 [PMID:8713977]

20. Bathgate RA and Sernia C. (1994) Characterization and localization of oxytocin receptors in the rat testis. J. Endocrinol. 141: 343-52 [PMID:8046305]

21. Bell IM, Erb JM, Freidinger RM, Gallicchio SN, Guare JP, Guidotti MT, Halpin RA, Hobbs DW, Homnick CF and Kuo MS et al.. (1998) Development of orally active oxytocin antagonists: studies on 1-(1-[4-[1-(2methyl-1-oxidopyridin-3-ylmethyl)piperidin-4-yloxy]-2- methoxybenzoyl]piperidin-4-yl)-1,4-dihydrobenz[d] [1,3]oxazin-2-one (L-372,662) and related pyridines. J. Med. Chem. 41: 2146-63 [PMID:9622556]

22. Ben-Efraim YJ, Wasserman D, Wasserman J and Sokolowski M. (2013) Family-based study of AVPR1B association and interaction with stressful life events on depression and anxiety in suicide attempts. Neuropsychopharmacology 38: 1504-11 [PMID:23422793]

23. Beretsos P, Loutradis D, Koussoulakos S, Margaritis LH, Kiapekou E, Mastorakos G, Papaspirou I, Makris N, Makrigiannakis A and Antsaklis A. (2006) Oxytocin receptor is differentially expressed in mouse endometrium and embryo during blastocyst implantation. Ann. N. Y. Acad. Sci. 1092: 466-79 [PMID:17308174]

24. Bichet DG. (2006) Nephrogenic diabetes insipidus. Adv Chronic Kidney Dis 13: 96-104 [PMID:16580609]

25. Bichet DG, Turner M and Morin D. (1998) Vasopressin receptor mutations causing nephrogenic diabetes insipidus. Proc. Assoc. Am. Physicians 110: 387-94 [PMID:9756088]

26. Bielsky IF, Hu SB, Ren X, Terwilliger EF and Young LJ. (2005) The V1a vasopressin receptor is necessary and sufficient for normal social recognition: a gene replacement study. Neuron 47: 503-513 [PMID:16102534]

27. Bielsky IF, Hu SB, Szegda KL, Westphal H and Young LJ. (2004) Profound impairment in social recognition and reduction in anxiety-like behavior in vasopressin V1a receptor knockout mice. Neuropsychopharmacology 29: 483-93 [PMID:14647484]

28. Bielsky IF, Hu SB and Young LJ. (2005) Sexual dimorphism in the vasopressin system: lack of an altered behavioral phenotype in female V1a receptor knockout mice. Behav. Brain Res. 164: 132-6 [PMID:16046007] 
29. Birnbaumer M. (1999) Vasopressin receptor mutations and nephrogenic diabetes insipidus.Arch. Med. Res. 30: 465-74 [PMID:10714359]

30. Birnbaumer M, Seibold A, Gilbert S, Ishido M, Barberis C, Antaramian A, Brabet P and Rosenthal W. (1992) Molecular cloning of the receptor for human antidiuretic hormone. Nature 357: 333-5 [PMID:1534149]

31. Birumachi J, Hiroyama M, Fujiwara Y, Aoyagi T, Sanbe A and Tanoue A. (2007) Impaired argininevasopressin-induced aldosterone release from adrenal gland cells in mice lacking the vasopressin $\mathrm{V} 1 \mathrm{~A}$ receptor. Eur. J. Pharmacol. 566: 226-30 [PMID:17449028]

32. Boone M and Deen PM. (2008) Physiology and pathophysiology of the vasopressin-regulated renal water reabsorption. Pflugers Arch. 456: 1005-24 [PMID:18431594]

33. Borthwick AD, Davies DE, Exall AM, Livermore DG, Sollis SL, Nerozzi F, Allen MJ, Perren M, Shabbir SS and Woollard PM et al.. (2005) 2,5-diketopiperazines as potent, selective, and orally bioavailable oxytocin antagonists. 2. Synthesis, chirality, and pharmacokinetics. J. Med. Chem. 48: 6956-69 [PMID:16250654]

34. Braga DC, Mori E, Higa KT, Morris M and Michelini LC. (2000) Central oxytocin modulates exerciseinduced tachycardia. Am. J. Physiol. Regul. Integr. Comp. Physiol.278: R1474-82 [PMID:10848513]

35. Breton C, Chellil H, Kabbaj-Benmansour M, Carnazzi E, Seyer R, Phalipou S, Morin D, Durroux T, Zingg H and Barberis $C$ et al.. (2001) Direct identification of human oxytocin receptor-binding domains using a photoactivatable cyclic peptide antagonist: comparison with the human V1a vasopressin receptor. J. Biol. Chem. 276: 26931-41 [PMID:11337500]

36. Breton C, Di Scala-Guenot D and Zingg HH. (2001) Oxytocin receptor gene expression in rat mammary gland: structural characterization and regulation. J. Mol. Endocrinol. 27: 175-89 [PMID:11564602]

37. Breton C, Pechoux C, Morel G and Zingg HH. (1995) Oxytocin receptor messenger ribonucleic acid: characterization, regulation, and cellular localization in the rat pituitary gland. Endocrinology 136: 2928-36 [PMID:7540544]

38. Briley EM, Lolait SJ, Axelrod J and Felder CC. (1994) The cloned vasopressin V1a receptor stimulates phospholipase $\mathrm{A} 2$, phospholipase $\mathrm{C}$, and phospholipase $\mathrm{D}$ through activation of receptor-operated calcium channels. Neuropeptides 27: 63-74 [PMID:7969820]

39. Brouard R, Laporte V, Serradeil Le Gal C, Pignol R, Jang H, Donat F, Lockwood G, Fournie D and Dreux F. (1998) Safety, tolerability, and pharmacokinetics of SR 49059, a V1a vasopressin receptor antagonist, after repeated oral administration in healthy volunteers. Adv. Exp. Med. Biol. 449: 455-65 [PMID:10026839]

40. Bussolati G, Cassoni P, Ghisolfi G, Negro F and Sapino A. (1996) Immunolocalization and gene expression of oxytocin receptors in carcinomas and non-neoplastic tissues of the breast. Am. J. Pathol. 148: 1895-903 [PMID:8669475]

41. Caldwell HK, Stewart J, Wiedholz LM, Millstein RA, lacangelo A, Holmes A, Young 3rd WS and Wersinger SR. (2006) The acute intoxicating effects of ethanol are not dependent on the vasopressin $1 \mathrm{a}$ or $1 \mathrm{~b}$ receptors. Neuropeptides 40: 325-37 [PMID:17049983]

42. Cash JD, Gader AM and da Costa J. (1974) Proceedings: The release of plasminogen activator and factor VIII to lysine vasopressin, arginine vasopressin, I-desamino-8-d-arginine vasopressin, angiotensin and oxytocin in man. Br. J. Haematol. 27: 363-4 [PMID:4367720]

43. Cassoni P, Marrocco T, Sapino A, Allia E and Bussolati G. (2004) Evidence of oxytocin/oxytocin receptor interplay in human prostate gland and carcinomas. Int. J. Oncol. 25: 899-904 [PMID:15375538]

44. Chan Seem CP, Dossetor JF and Penney MD. (1999) Nephrogenic diabetes insipidus due to a new mutation of the arginine vasopressin V2 receptor gene in a girl presenting with non-accidental injury. Ann. Clin. Biochem. 36 ( Pt 6): 779-82 [PMID:10586320]

45. Chan WY and Chen DL. (1992) Myometrial oxytocin receptors and prostaglandin in the parturition process in the rat. Biol. Reprod. 46: 58-64 [PMID:1312364]

46. Chandrashekhar Y, Prahash AJ, Sen S, Gupta S, Roy S and Anand IS. (2003) The role of arginine vasopressin and its receptors in the normal and failing rat heart. J. Mol. Cell. Cardiol. 35: 495-504 [PMID:12738231] 
47. Charles R, Sakurai T, Takahashi N, Elder GA, Gama Sosa MA, Young LJ and Buxbaum JD. (2014) Introduction of the human AVPR1A gene substantially alters brain receptor expression patterns and enhances aspects of social behavior in transgenic mice. Dis Model Mech 7: 1013-22 [PMID:24924430]

48. Chen YL, Shepherd C, Spinelli W and Lai FM. (1999) Oxytocin and vasopressin constrict rat isolated uterine resistance arteries by activating vasopressin V1A receptors. Eur J Pharmaco/376: 45-51 [PMID:10440088]

49. Cheng LL, Stoev S, Manning M, Derick S, Pena A, Mimoun MB and Guillon G. (2004) Design of potent and selective agonists for the human vasopressin $\mathrm{V} 1 \mathrm{~b}$ receptor based on modifications of [deaminocys1]arginine vasopressin at position 4. J Med Chem 47: 2375-2388 [PMID:15084136]

50. Cheong HI, Park HW, Ha IS, Moon HN, Choi Y, Ko KW and Jun JK. (1997) Six novel mutations in the vasopressin V2 receptor gene causing nephrogenic diabetes insipidus. Nephron 75: 431-7 [PMID:9127330]

51. Chini B, Chinol M, Cassoni P, Papi S, Reversi A, Areces L, Marrocco T, Paganelli G, Manning M and Bussolati G. (2003) Improved radiotracing of oxytocin receptor-expressing tumours using the new [111In]DOTA-Lys8-deamino-vasotocin analogue. Br. J. Cancer 89: 930-6 [PMID:12942128]

52. Chini B, Manning M and Guillon G. (2008) Affinity and efficacy of selective agonists and antagonists for vasopressin and oxytocin receptors: an "easy guide" to receptor pharmacology. Prog. Brain Res. 170: 5137 [PMID:18655904]

53. Chini B, Mouillac B, Ala Y, Balestre MN, Trumpp-Kallmeyer S, Hoflack J, Elands J, Hibert M, Manning M and Jard $\mathrm{S}$ et al.. (1995) Tyr115 is the key residue for determining agonist selectivity in the V1a vasopressin receptor. EMBO J. 14: 2176-82 [PMID:7774575]

54. Chini B, Mouillac B, Balestre MN, Trumpp-Kallmeyer S, Hoflack J, Hibert M, Andriolo M, Pupier S, Jard S and Barberis C. (1996) Two aromatic residues regulate the response of the human oxytocin receptor to the partial agonist arginine vasopressin. FEBS Lett. 397: 201-6 [PMID:8955347]

55. Chou CL, DiGiovanni SR, Luther A, Lolait SJ and Knepper MA. (1995) Oxytocin as an antidiuretic hormone. II. Role of V2 vasopressin receptor. Am J Physiol 269: F78-F85 [PMID:7631834]

56. Cirillo R, Gillio Tos E, Schwarz MK, Quattropani A, Scheer A, Missotten M, Dorbais J, Nichols A, Borrelli F and Giachetti $C$ et al.. (2003) Pharmacology of (2S,4Z)-N-[(2S)-2-hydroxy-2-phenylethyl]-4-(methoxyimino) -1-[(2'-methyl[1,1'-biphenyl]-4-yl)carbonyl]-2-pyrrolidinecarboxamide, a new potent and selective nonpeptide antagonist of the oxytocin receptor. J. Pharmacol. Exp. Ther. 306: 253-61 [PMID:12660315]

57. Clerget MS, Elalouf JM and Germain G. (1997) Quantitative reverse transcription and polymerase chain reaction analysis of oxytocin and vasopressin receptor mRNAs in the rat uterus near parturition. $\mathrm{Mol}$ Cell Endocrinol 136: 79-89 [PMID:9510070]

58. Colucci S, Colaianni G, Mori G, Grano M and Zallone A. (2002) Human osteoclasts express oxytocin receptor. Biochem. Biophys. Res. Commun. 297: 442-5 [PMID:12270111]

59. Copland JA, Ives KL, Simmons DJ and Soloff MS. (1999) Functional oxytocin receptors discovered in human osteoblasts. Endocrinology 140: 4371-4 [PMID:10465312]

60. Cotte N, Balestre MN, Aumelas A, Mahé E, Phalipou S, Morin D, Hibert M, Manning M, Durroux T and Barberis $C$ et al.. (2000) Conserved aromatic residues in the transmembrane region VI of the V1a vasopressin receptor differentiate agonist vs. antagonist ligand binding. Eur. J. Biochem. 267: 4253-63 [PMID:10866830]

61. Cotte N, Balestre MN, Phalipou S, Hibert M, Manning M, Barberis C and Mouillac B. (1998) Identification of residues responsible for the selective binding of peptide antagonists and agonists in the V2 vasopressin receptor. J. Biol. Chem. 273: 29462-8 [PMID:9792651]

62. Crawley JN, Chen T, Puri A, Washburn R, Sullivan TL, Hill JM, Young NB, Nadler JJ, Moy SS and Young LJ et al.. (2007) Social approach behaviors in oxytocin knockout mice: comparison of two independent lines tested in different laboratory environments. Neuropeptides 41: 145-63 [PMID:17420046]

63. Croiset $G$ and De Wied D. (1997) Proconvulsive effect of vasopressin; mediation by a putative V2 receptor subtype in the central nervous system. Brain Res. 759: 18-23 [PMID:9219858]

64. Crombie AL, Antrilli TM, Campbell BA, Crandall DL, Failli AA, He Y, Kern JC, Moore WJ, Nogle LM and 
Trybulski EJ. (2010) Synthesis and evaluation of azabicyclo[3.2.1]octane derivatives as potent mixed vasopressin antagonists. Bioorg. Med. Chem. Lett. 20: 3742-5 [PMID:20471258]

65. Daikoku R, Kunitake T, Kato K, Tanoue A, Tsujimoto G and Kannan H. (2007) Body water balance and body temperature in vasopressin $\mathrm{V} 1 \mathrm{~b}$ receptor knockout mice. Auton Neurosci 136: 58-62 [PMID:17512263]

66. de Keyzer Y, Auzan C, Lenne F, Beldjord C, Thibonnier M, Bertagna X and Clauser E. (1994) Cloning and characterization of the human V3 pituitary vasopressin receptor. FEBS Lett. 356: 215-20 [PMID:7805841]

67. de Wied D, Diamant M and Fodor M. (1993) Central nervous system effects of the neurohypophyseal hormones and related peptides. Front Neuroendocrinol 14: 251-302 [PMID:8258377]

68. Deen PM and Knoers NV. (1998) Vasopressin type-2 receptor and aquaporin-2 water channel mutants in nephrogenic diabetes insipidus. Am. J. Med. Sci. 316: 300-9 [PMID:9822112]

69. Dempster EL, Burcescu I, Wigg K, Kiss E, Baji I, Gadoros J, Tamás Z, Kennedy JL, Vetró A and Kovacs M et al.. (2007) Evidence of an association between the vasopressin V1b receptor gene (AVPR1B) and childhood-onset mood disorders. Arch. Gen. Psychiatry 64: 1189-95 [PMID:17909131]

70. Derick S, Cheng LL, Voirol MJ, Stoev S, Giacomini M, Wo NC, Szeto HH, Ben Mimoun M, Andres M and Gaillard RC et al.. (2002) [1-deamino-4-cyclohexylalanine] arginine vasopressin: a potent and specific agonist for vasopressin V1b receptors. Endocrinology 143: 4655-64 [PMID:12446593]

71. Diaz Brinton R and Brownson EA. (1993) Vasopressin-induction of cyclic AMP in cultured hippocampal neurons. Brain Res. Dev. Brain Res. 71: 101-5 [PMID:8381727]

72. Dong Y, Sheng H, Chen X, Yin J and Su Q. (2006) Deletion of the V2 vasopressin receptor gene in two Chinese patients with nephrogenic diabetes insipidus. BMC Genet 7: 53-53 [PMID:17101063]

73. Du Vigneaud V, Ressler C and Trippett S. (1953) The sequence of amino acids in oxytocin, with a proposal for the structure of oxytocin. J Biol Chem 205: 949-957 [PMID:13129273]

74. Dutil J, Moujahidine M, Lemieux C, Jankowski M, Gutkowska J and Deng AY. (2001) Chromosomal and comparative mapping of rat oxytocin, oxytocin receptor and vasopressin genes. Cytogenet. Cell Genet. 93: 57-9 [PMID:11474180]

75. Ebstein RP, Knafo A, Mankuta D, Chew SH and Lai PS. (2012) The contributions of oxytocin and vasopressin pathway genes to human behavior. Horm Behav 61: 359-79 [PMID:22245314]

76. Egashira N, Tanoue A, Higashihara F, Fuchigami H, Sano K, Mishima K, Fukue Y, Nagai H, Takano Y and Tsujimoto $\mathrm{G}$ et al.. (2005) Disruption of the prepulse inhibition of the startle reflex in vasopressin $\mathrm{V} 1 \mathrm{~b}$ receptor knockout mice: reversal by antipsychotic drugs. Neuropsychopharmacology 30: 1996-2005 [PMID:15956991]

77. Egashira N, Tanoue A, Higashihara F, Mishima K, Fukue Y, Takano Y, Tsujimoto G, Iwasaki K and Fujiwara M. (2004) V1a receptor knockout mice exhibit impairment of spatial memory in an eight-arm radial maze. Neurosci. Lett. 356: 195-8 [PMID:15036628]

78. Egashira N, Tanoue A, Matsuda T, Koushi E, Harada S, Takano Y, Tsujimoto G, Mishima K, Iwasaki K and Fujiwara M. (2007) Impaired social interaction and reduced anxiety-related behavior in vasopressin V1a receptor knockout mice. Behav. Brain Res. 178: 123-7 [PMID:17227684]

79. Elands J, Barberis C and Jard S. (1988) [3H]-[Thr4,Gly7]OT: a highly selective ligand for central and peripheral OT receptors. Am. J. Physiol. 254: E31-8 [PMID:2827511]

80. Elands J, Beetsma A, Barberis $C$ and de Kloet ER. (1988) Topography of the oxytocin receptor system in rat brain: an autoradiographical study with a selective radioiodinated oxytocin antagonist. J. Chem. Neuroanat. 1: 293-302 [PMID:2855912]

81. Elands J, Resink A and De Kloet ER. (1988) Oxytocin receptors in the rat thymic glandEur J Pharmacol 151: 345-346 [PMID:2844558]

82. Engstrøm T, Atke A and Vilhardt $\mathrm{H}$. (1988) Oxytocin receptors and contractile response of the myometrium after long term infusion of prostaglandin F2 alpha, indomethacin, oxytocin and an oxytocin antagonist in rats. Regul. Pept. 20: 65-72 [PMID:2832879]

83. Failli AA, Shumsky JS, Steffan RJ, Caggiano TJ, Williams DK, Trybulski EJ, Ning X, Lock Y, Tanikella T and Hartmann D et al.. (2006) Pyridobenzodiazepines: a novel class of orally active, vasopressin V2 
receptor selective agonists. Bioorg. Med. Chem. Lett. 16: 954-9 [PMID:16297621]

84. Fay MJ, Du J, Yu X and North WG. (1996) Evidence for expression of vasopressin V2 receptor mRNA in human lung. Peptides 17: 477-481 [PMID:8735975]

85. Feldman BJ, Rosenthal SM, Vargas GA, Fenwick RG, Huang EA, Matsuda-Abedini M, Lustig RH, Mathias RS, Portale AA and Miller WL et al.. (2005) Nephrogenic syndrome of inappropriate antidiuresis.N. Engl. J. Med. 352: 1884-90 [PMID:15872203]

86. Fenton RA, Brønd L, Nielsen S and Praetorius J. (2007) Cellular and subcellular distribution of the type-2 vasopressin receptor in the kidney. Am J Physiol Renal Physiol 293: F748-F760 [PMID:17553938]

87. Ferguson JN, Young LJ, Hearn EF, Matzuk MM, Insel TR and Winslow JT. (2000) Social amnesia in mice lacking the oxytocin gene. Nat. Genet. 25: 284-8 [PMID:10888874]

88. Filippi S, Vannelli GB, Granchi S, Luconi M, Crescioli C, Mancina R, Natali A, Brocchi S, Vignozzi L and Bencini $E$ et al.. (2002) Identification, localization and functional activity of oxytocin receptors in epididymis. Mol. Cell. Endocrinol. 193: 89-100 [PMID:12161007]

89. Firsov D, Mandon B, Morel A, Merot J, Le Maout S, Bellanger AC, de Rouffignac C, Elalouf JM and Buhler JM. (1994) Molecular analysis of vasopressin receptors in the rat nephron. Evidence for alternative splicing of the V2 receptor. Pflugers Arch. 429: 79-89 [PMID:7708485]

90. Foletta VC, Brown FD and Young 3rd WS. (2002) Cloning of rat ARHGAP4/C1, a RhoGAP family member expressed in the nervous system that colocalizes with the Golgi complex and microtubules. Brain Res. Mol. Brain Res. 107: 65-79 [PMID:12414125]

91. Folny V, Raufaste D, Lukovic L, Pouzet B, Rochard P, Pascal M and Serradeil-Le Gal C. (2003) Pancreatic vasopressin V1b receptors: characterization in In-R1-G9 cells and localization in human pancreas. Am. J. Physiol. Endocrinol. Metab. 285: E566-76 [PMID:12736162]

92. Foord SM, Bonner TI, Neubig RR, Rosser EM, Pin JP, Davenport AP, Spedding M and Harmar AJ. (2005) International Union of Pharmacology. XLVI. G protein-coupled receptor list. Pharmacol. Rev. 57: 279-88 [PMID:15914470]

93. Fragiadaki M, Magafa V, Borovicková L, Slaninová J and Cordopatis P. (2007) Synthesis and biological activity of oxytocin analogues containing conformationally-restricted residues in position 7. Eur J Med Chem 42: 799-806 [PMID:17316912]

94. Fuchs AR, Fuchs F, Husslein P, Soloff MS and Fernström MJ. (1982) Oxytocin receptors and human parturition: a dual role for oxytocin in the initiation of labor. Science 215: 1396-8 [PMID:6278592]

95. Fujiwara TM and Bichet DG. (2005) Molecular biology of hereditary diabetes insipidus J. Am. Soc. Nephrol. 16: 2836-46 [PMID:16093448]

96. Fujiwara Y, Hiroyama M, Sanbe A, Aoyagi T, Birumachi J, Yamauchi J, Tsujimoto G and Tanoue A. (2007) Insulin hypersensitivity in mice lacking the V1b vasopressin receptor. J. Physiol. (Lond.) 584: 23544 [PMID:17673508]

97. Fujiwara Y, Hiroyama M, Sanbe A, Yamauchi J, Tsujimoto G and Tanoue A. (2007) Mutual regulation of vasopressin- and oxytocin-induced glucagon secretion in $\mathrm{V} 1 \mathrm{~b}$ vasopressin receptor knockout mice. $\mathrm{J}$. Endocrinol. 192: 361-9 [PMID:17283236]

98. Furuya K, Mizumoto Y, Makimura N, Mitsui C, Murakami M, Tokuoka S, Ishikawa N, Imaizumi E, Katayama E and Seki K et al.. (1995) Gene expressions of oxytocin and oxytocin receptor in cumulus cells of human ovary. Horm. Res. 44 Suppl 2: 47-9 [PMID:7545643]

99. Gaillard RC, Schoenenberg P, Favrod-Coune CA, Muller AF, Marie J, Bockaert J and Jard S. (1984) Properties of rat anterior pituitary vasopressin receptors: relation to adenylate cyclase and the effect of corticotropin-releasing factor. Proc. Natl. Acad. Sci. U.S.A. 81: 2907-11 [PMID:6326152]

100. Gimpl $G$ and Fahrenholz F. (2001) The oxytocin receptor system: structure, function, and regulation. Physiol. Rev. 81: 629-83 [PMID:11274341]

101. Gitelman SE, Feldman BJ and Rosenthal SM. (2006) Nephrogenic syndrome of inappropriate antidiuresis: a novel disorder in water balance in pediatric patients. Am J Med 119: S54-S58 [PMID:16843086]

102. Grazzini E, Boccara G, Joubert D, Trueba M, Durroux T, Guillon G, Gallo-Payet N, Chouinard L, Payet MD and Serradeil Le Gal C. (1998) Vasopressin regulates adrenal functions by acting through different 
vasopressin receptor subtypes. Adv. Exp. Med. Biol. 449: 325-34 [PMID:10026821]

103. Grazzini E, Breton C, Derick S, Andres M, Raufaste D, Rickwaert F, Boccara G, Colson P, Guérineau NC and Serradeil-le Gal C et al.. (1999) Vasopressin receptors in human adrenal medulla and pheochromocytoma. J. Clin. Endocrinol. Metab. 84: 2195-203 [PMID:10372731]

104. Grazzini E, Lodboerer AM, Perez-Martin A, Joubert D and Guillon G. (1996) Molecular and functional characterization of V1b vasopressin receptor in rat adrenal medulla. Endocrinology 137: 3906-3914 [PMID:8756565]

105. Griebel G, Simiand J, Serradeil-Le Gal C, Wagnon J, Pascal M, Scatton B, Maffrand JP and Soubrie P. (2002) Anxiolytic- and antidepressant-like effects of the non-peptide vasopressin V1b receptor antagonist, SSR149415, suggest an innovative approach for the treatment of stress-related disorders. Proc. Natl. Acad. Sci. U.S.A. 99: 6370-5 [PMID:11959912]

106. Griffante C, Green A, Curcuruto O, Haslam CP, Dickinson BA and Arban R. (2005) Selectivity of d[Cha4]AVP and SSR149415 at human vasopressin and oxytocin receptors: evidence that SSR149415 is a mixed vasopressin V1b/oxytocin receptor antagonist. Br J Pharmacol 146: 744-751 [PMID:16158071]

107. Guillon G, Grazzini E, Andrez M, Breton C, Trueba M, Serradeil-LeGal C, Boccara G, Derick S, Chouinard L and Gallo-Payet N. (1998) Vasopressin : a potent autocrine/paracrine regulator of mammal adrenal functions. Endocr. Res. 24: 703-10 [PMID:9888562]

108. Gunnet JW, Matthews JM, Maryanoff BE, de Garavilla L, Andrade-Gordon P, Damiano B, Hageman W, Look R, Stahle P and Streeter AJ et al.. (2006) Characterization of RWJ-351647, a novel nonpeptide vasopressin V2 receptor antagonist. Clin. Exp. Pharmacol. Physiol. 33: 320-6 [PMID:16620295]

109. Gutkowska J, Jankowski M, Lambert C, Mukaddam-Daher S, Zingg HH and McCann SM. (1997) Oxytocin releases atrial natriuretic peptide by combining with oxytocin receptors in the heart. Proc Natl Acad Sci U S A 94: 11704-11709 [PMID:9326674]

110. Hammock EA, Law CS and Levitt P. (2013) Vasopressin eliminates the expression of familiar odor bias in neonatal female mice through V1aR. Horm Behav 63: 352-60 [PMID:23261858]

111. Hansenne I, Rasier G, Péqueux C, Brilot F, Renard Ch, Breton C, Greimers R, Legros JJ, Geenen V and Martens HJ. (2005) Ontogenesis and functional aspects of oxytocin and vasopressin gene expression in the thymus network. J. Neuroimmunol. 158: 67-75 [PMID:15589039]

112. Hasan KN, Shoji M, Tsutaya S, Kudo R, Matsuda E, Saito J, Kimura T and Yasujima M. (2006) Study of V1a vasopressin receptor gene single nucleotide polymorphisms in platelet vasopressin responsiveness. $J$. Clin. Lab. Anal. 20: 87-92 [PMID:16721832]

113. Hassan A, Tian Y, Zheng W, Ji H, Sandberg K and Verbalis JG. (2005) Small interfering RNA-mediated functional silencing of vasopressin V2 receptors in the mouse kidney. Physiol. Genomics 21: 382-8 [PMID:15784697]

114. Hernando F, Schoots O, Lolait SJ and Burbach JP. (2001) Immunohistochemical localization of the vasopressin $\mathrm{V} 1 \mathrm{~b}$ receptor in the rat brain and pituitary gland: anatomical support for its involvement in the central effects of vasopressin. Endocrinology 142: 1659-68 [PMID:11250948]

115. Hirasawa A, Hashimoto $K$ and Tsujimoto G. (1994) Distribution and developmental change of vasopressin V1A and V2 receptor mRNA in rats. Eur. J. Pharmacol. 267: 71-5 [PMID:8206132]

116. Hirasawa A, Nakayama Y, Ishiharada N, Honda K, Saito R, Tsujimoto G, Takano Y and Kamiya H. (1994) Evidence for the existence of vasopressin V2 receptor mRNA in rat hippocampus. Biochem. Biophys. Res. Commun. 205: 1702-6 [PMID:7811254]

117. Hiroyama M, Aoyagi T, Fujiwara Y, Birumachi J, Shigematsu Y, Kiwaki K, Tasaki R, Endo F and Tanoue A. (2007) Hypermetabolism of fat in V1a vasopressin receptor knockout mice. Mol Endocrinol 21: 247-258 [PMID:17021052]

118. Hiroyama M, Aoyagi T, Fujiwara Y, Oshikawa S, Sanbe A, Endo F and Tanoue A. (2007) Hyperammonaemia in V1a vasopressin receptor knockout mice caused by the promoted proteolysis and reduced intrahepatic blood volume. J. Physiol. (Lond.) 581: 1183-92 [PMID:17379633]

119. Hiroyama M, Wang S, Aoyagi T, Oikawa R, Sanbe A, Takeo S and Tanoue A. (2007) Vasopressin promotes cardiomyocyte hypertrophy via the vasopressin $\mathrm{V} 1 \mathrm{~A}$ receptor in neonatal mice. Eur. J. 
Pharmacol. 559: 89-97 [PMID:17275806]

120. Huang W, Sjöquist M, Skott O, Stricker EM and Sved AF. (2000) Oxytocin-induced renin secretion in conscious rats. Am J Physiol Regul Integr Comp Physiol 278: R226-R230 [PMID:10644643]

121. Inaba S, Hatakeyama $\mathrm{H}$, Taniguchi $\mathrm{N}$ and Miyamori I. (2001) The property of a novel v2 receptor mutant in a patient with nephrogenic diabetes insipidus. J. Clin. Endocrinol. Metab. 86: 381-5 [PMID:11232028]

122. Itoh S, Yamada S, Mori T, Miwa T, Tottori K, Uwahodo Y, Yamamura Y, Fukuda M, Yamamoto K and Tanoue A et al.. (2006) Attenuated stress-induced catecholamine release in mice lacking the vasopressin V1b receptor. Am. J. Physiol. Endocrinol. Metab. 291: E147-51 [PMID:16464910]

123. Ivell $R$ and Richter D. (1984) Structure and comparison of the oxytocin and vasopressin genes from rat. Proc. Natl. Acad. Sci. U.S.A. 81: 2006-10 [PMID:6326097]

124. Jacob S, Brune CW, Carter CS, Leventhal BL, Lord C and Cook Jr EH. (2007) Association of the oxytocin receptor gene (OXTR) in Caucasian children and adolescents with autism. Neurosci. Lett. 417: 6-9 [PMID:17383819]

125. Jankowski M, Danalache B, Wang D, Bhat P, Hajjar F, Marcinkiewicz M, Paquin J, McCann SM and Gutkowska J. (2004) Oxytocin in cardiac ontogeny. Proc. Natl. Acad. Sci. U.S.A. 101: 13074-9 [PMID:15316117]

126. Jard S, Gaillard RC, Guillon G, Marie J, Schoenenberg P, Muller AF, Manning M and Sawyer WH. (1986) Vasopressin antagonists allow demonstration of a novel type of vasopressin receptor in the rat adenohypophysis. Mol. Pharmacol. 30: 171-7 [PMID:3016500]

127. Jasper JR, Harrell CM, O'Brien JA and Pettibone DJ. (1995) Characterization of the human oxytocin receptor stably expressed in 293 human embryonic kidney cells. Life Sci. 57: 2253-61 [PMID:7475979]

128. Jean-Alphonse F, Perkovska S, Frantz MC, Durroux T, Méjean C, Morin D, Loison S, Bonnet D, Hibert M and Mouillac B et al.. (2009) Biased agonist pharmacochaperones of the AVP V2 receptor may treat congenital nephrogenic diabetes insipidus. J. Am. Soc. Nephrol. 20: 2190-203 [PMID:19729439]

129. Jeng YJ, Lolait SJ, Strakova Z, Chen C, Copland JA, Mellman D, Hellmich MR and Soloff MS. (1996) Molecular cloning and functional characterization of the oxytocin receptor from a rat pancreatic cell line (RINm5F). Neuropeptides 30: 557-65 [PMID:9004255]

130. Johnston Cl. (1985) Vasopressin in circulatory control and hypertension.J. Hypertens. 3: 557-69 [PMID:2935570]

131. Kamperis K, Siggaard C, Herlin T, Nathan E, Hertz JM and Rittig S. (2000) A novel splicing mutation in the V2 vasopressin receptor. Pediatr. Nephrol. 15: 43-9 [PMID:11095010]

132. Kato Y, Igarashi N, Hirasawa A, Tsujimoto G and Kobayashi M. (1995) Distribution and developmental changes in vasopressin V2 receptor mRNA in rat brain. Differentiation 59: 163-9 [PMID:7589900]

133. Keck ME, Kern N, Erhardt A, Unschuld PG, Ising M, Salyakina D, Müller MB, Knorr CC, Lieb R and Hohoff $C$ et al.. (2008) Combined effects of exonic polymorphisms in CRHR1 and AVPR1B genes in a case/control study for panic disorder. Am. J. Med. Genet. B Neuropsychiatr. Genet. 147B: 1196-204 [PMID:18384079]

134. Kiberd B, Robertson CR, Larson T and Jamison RL. (1987) Effect of V2-receptor-mediated changes on inner medullary blood flow induced by AVP. Am. J. Physiol. 253: F576-81 [PMID:2957929]

135. Kikuchi S, Tanoue A, Goda N, Matsuo N and Tsujimoto G. (1999) Structure and sequence of the mouse V1a and V1b vasopressin receptor genes. Jpn J Pharmacol. 81: 388-392 [PMID:10669045]

136. Kim SJ, Young LJ, Gonen D, Veenstra-VanderWeele J, Courchesne R, Courchesne E, Lord C, Leventhal BL, Cook Jr EH and Insel TR. (2002) Transmission disequilibrium testing of arginine vasopressin receptor 1A (AVPR1A) polymorphisms in autism. Mol. Psychiatry 7: 503-7 [PMID:12082568]

137. Kimura T. (1995) Investigation of the oxytocin receptor at the molecular level.Adv. Exp. Med. Biol. 395: 259-68 [PMID:8713976]

138. Kimura $T$, Ito $Y$, Einspanier $A$, Tohya $K$, Nobunaga $T$, Tokugawa $Y$, Takemura $M$, Kubota $Y$, Ivell $R$ and Matsuura $\mathrm{N}$ et al.. (1998) Expression and immunolocalization of the oxytocin receptor in human lactating and non-lactating mammary glands. Hum. Reprod. 13: 2645-53 [PMID:9806301]

139. Kimura T, Makino Y, Saji F, Takemura M, Inoue T, Kikuchi T, Kubota Y, Azuma C, Nobunaga T and 
Tokugawa Y et al.. (1994) Molecular characterization of a cloned human oxytocin receptor.Eur. J. Endocrinol. 131: 385-90 [PMID:7921228]

140. Kimura T, Tanizawa O, Mori K, Brownstein MJ and Okayama H. (1992) Structure and expression of a human oxytocin receptor. Nature 356: 526-9 [PMID:1313946]

141. Kirk CJ, Rodrigues LM and Hems DA. (1979) The influence of vasopressin and related peptides on glycogen phosphorylase activity and phosphatidylinositol metabolism in hepatocytes. Biochem. J. 178: 493-6 [PMID:444224]

142. Klingler C, Preisser L, Barrault MB, Lluel P, Horgen L, Teillet L, Ancellin N and Corman B. (1997) Vasopressin $\mathrm{V} 2$ receptor mRNA expression and cAMP accumulation in aging rat kidney. Am. J. Physiol. 272: R1775-82 [PMID:9227590]

143. Knafo A, Israel S, Darvasi A, Bachner-Melman R, Uzefovsky F, Cohen L, Feldman E, Lerer E, Laiba E and Raz $Y$ et al.. (2008) Individual differences in allocation of funds in the dictator game associated with length of the arginine vasopressin 1a receptor RS3 promoter region and correlation between RS3 length and hippocampal mRNA. Genes Brain Behav. 7: 266-75 [PMID:17696996]

144. Knoers NV, van den Ouweland AM, Verdijk M, Monnens LA and van Oost BA. (1994) Inheritance of mutations in the $\mathrm{V} 2$ receptor gene in thirteen families with nephrogenic diabetes insipidus. Kidney Int. 46: 170-6 [PMID:7933835]

145. Kosfeld M, Heinrichs M, Zak PJ, Fischbacher U and Fehr E. (2005) Oxytocin increases trust in humans. Nature 435: 673-6 [PMID:15931222]

146. Koshimizu TA, Nasa Y, Tanoue A, Oikawa R, Kawahara Y, Kiyono Y, Adachi T, Tanaka T, Kuwaki T, Mori T, Takeo S, Okamura $H$ and Tsujimoto G. (2006) V1a vasopressin receptors maintain normal blood pressure by regulating circulating blood volume and baroreflex sensitivity. Proc Natl Acad Sci U S A103: 7807-7812 [PMID:16682631]

147. Kotnik P, Battelino T, Debeljak M, Podkrajsek KT, Waldhauser F, Frøkiaer J, Nielsen S and Krzisnik C. (2007) Correlation between AVPR2 mutations and urinary AQP2 excretion in patients with nephrogenic diabetes insipidus. J Pediatr Endocrinol Metab 20: 483-489 [PMID:17550212]

148. Kubota Y, Kimura T, Hashimoto K, Tokugawa Y, Nobunaga K, Azuma C, Saji F and Murata Y. (1996) Structure and expression of the mouse oxytocin receptor gene. Mol. Cell. Endocrinol. 124: 25-32 [PMID:9027321]

149. Kumagami H, Loewenheim H, Beitz E, Wild K, Schwartz H, Yamashita K, Schultz J, Paysan J, Zenner HP and Ruppersberg JP. (1998) The effect of anti-diuretic hormone on the endolymphatic sac of the inner ear. Pflugers Arch. 436: 970-5 [PMID:9799415]

150. Laugwitz KL, Ungerer M, Schöneberg T, Weig HJ, Kronsbein K, Moretti A, Hoffmann K, Seyfarth M, Schultz $G$ and Schömig A. (1999) Adenoviral gene transfer of the human V2 vasopressin receptor improves contractile force of rat cardiomyocytes. Circulation 99: 925-33 [PMID:10027817]

151. Lee B, Yang C, Chen TH, al-Azawi N and Hsu WH. (1995) Effect of AVP and oxytocin on insulin release: involvement of V1b receptors. Am. J. Physiol. 269: E1095-100 [PMID:8572202]

152. Lemaire W, O'Brien JA, Burno M, Chaudhary AG, Dean DC, Williams PD, Freidinger RM, Pettibone DJ and Williams DL. (2002) A nonpeptide oxytocin receptor antagonist radioligand highly selective for human receptors. Eur. J. Pharmacol. 450: 19-28 [PMID:12176104]

153. Leszczyńska-Rodziewicz A, Maciukiewicz M, Szczepankiewicz A, Pogłodziński A and Hauser J. (2013) Association between OPCRIT dimensions and polymorphisms of HPA axis genes in bipolar disorder. $J$ Affect Disord 151: 744-7 [PMID:24012103]

154. Levin R, Heresco-Levy U, Bachner-Melman R, Israel S, Shalev I and Ebstein RP. (2009) Association between arginine vasopressin 1a receptor (AVPR1a) promoter region polymorphisms and prepulse inhibition. Psychoneuroendocrinology 34: 901-8 [PMID:19195791]

155. Lim MM, Bielsky IF and Young LJ. (2005) Neuropeptides and the social brain: potential rodent models of autism. Int. J. Dev. Neurosci. 23: 235-43 [PMID:15749248]

156. Lim MM, Wang Z, Olazábal DE, Ren X, Terwilliger EF and Young LJ. (2004) Enhanced partner preference in a promiscuous species by manipulating the expression of a single gene. Nature 429: 754-7 
[PMID:15201909]

157. Liu CX, Takahashi S, Murata T, Hashimoto K, Agatsuma T, Matsukawa S and Higuchi T. (1996) Changes in oxytocin receptor mRNA in the rat uterus measured by competitive reverse transcription-polymerase chain reaction. J. Endocrinol. 150: 479-86 [PMID:8882167]

158. Loichot C, Grima M, De Jong W, Helwig JJ, Imbs JL and Barthelmebs M. (2002) Oxytocin-induced renin secretion by denervated kidney in anaesthetized rat. Eur. J. Pharmacol. 454: 241-7 [PMID:12421653]

159. Loichot C, Krieger JP, De Jong W, Nisato D, Imbs JL and Barthelmebs M. (2001) High concentrations of oxytocin cause vasoconstriction by activating vasopressin $\mathrm{V} 1 \mathrm{~A}$ receptors in the isolated perfused rat kidney. Naunyn Schmiedebergs Arch. Pharmacol. 363: 369-75 [PMID:11330329]

160. Lolait SJ, O'Carroll AM, Mahan LC, Felder CC, Button DC, Young 3rd WS, Mezey E and Brownstein MJ. (1995) Extrapituitary expression of the rat V1b vasopressin receptor gene. Proc. Natl. Acad. Sci. U.S.A. 92 : 6783-7 [PMID:7624319]

161. Lolait SJ, O'Carroll AM, McBride OW, Konig M, Morel A and Brownstein MJ. (1992) Cloning and characterization of a vasopressin $\mathrm{V} 2$ receptor and possible link to nephrogenic diabetes insipidus. Nature. 357: 336-339 [PMID:1534150]

162. Lolait SJ, Roper JA, Hazell GGJ, Li Y, Thomson FJ and O'Carroll AM. (2016) Neuropeptide receptors $n$ Molecular Neuroendocrinology: From Genome to Physiology Edited by Murphy D, Gainer H: John Wiley \& Sons, Ltd.: 195-215

163. Lolait SJ, Stewart LQ, Jessop DS, Young 3rd WS and O'Carroll AM. (2007) The hypothalamic-pituitaryadrenal axis response to stress in mice lacking functional vasopressin $\mathrm{V} 1 \mathrm{~b}$ receptors. Endocrinology 148: 849-56 [PMID:17122081]

164. Lolait SJ, Stewart LQ, Roper JA, Harrison G, Jessop DS, Young 3rd WS and O'Carroll AM. (2007) Attenuated stress response to acute lipopolysaccharide challenge and ethanol administration in vasopressin V1b receptor knockout mice. J. Neuroendocrinol. 19: 543-51 [PMID:17561882]

165. Loup F, Tribollet E, Dubois-Dauphin M, Pizzolato G and Dreifuss JJ. (1989) Localization of oxytocin binding sites in the human brainstem and upper spinal cord: an autoradiographic study. Brain Res. 500: 223-30 [PMID:2557960]

166. Manning M, Cheng LL, Stoev S, Wo NC, Chan WY, Szeto HH, Durroux T, Mouillac B and Barberis C. (2005) Design of peptide oxytocin antagonists with strikingly higher affinities and selectivities for the human oxytocin receptor than atosiban. J. Pept. Sci. 11: 593-608 [PMID:15880385]

167. Manning M, Stoev S, Chini B, Durroux T, Mouillac B and Guillon G. (2008) Peptide and non-peptide agonists and antagonists for the vasopressin and oxytocin V1a, V1b, V2 and OT receptors: research tools and potential therapeutic agents. Prog. Brain Res. 170: 473-512 [PMID:18655903]

168. Mannucci PM. (1997) Desmopressin (DDAVP) in the treatment of bleeding disorders: the first 20 years. Blood 90: 2515-21 [PMID:9326215]

169. McCafferty GP, Pullen MA, Wu C, Edwards RM, Allen MJ, Woollard PM, Borthwick AD, Liddle J, Hickey DM and Brooks DP et al.. (2007) Use of a novel and highly selective oxytocin receptor antagonist to characterize uterine contractions in the rat. Am. J. Physiol. Regul. Integr. Comp. Physiol.293: R299-305 [PMID:17395790]

170. Meidan R and Hsueh AJ. (1985) Identification and characterization of arginine vasopressin receptors in the rat testis. Endocrinology 116: 416-23 [PMID:2981073]

171. Michelini S, Urbanek M, Dean M and Goldman D. (1995) Polymorphism and genetic mapping of the human oxytocin receptor gene on chromosome 3. Am J Med Genet 60: 183-187 [PMID:7573168]

172. Michell RH, Kirk CJ and Billah MM. (1979) Hormonal stimulation of phosphatidylinositol breakdown with particular reference to the hepatic effects of vasopressin. Biochem. Soc. Trans. 7: 861-5 [PMID:510730]

173. Morel A, O'Carroll AM, Brownstein MJ and Lolait SJ. (1992) Molecular cloning and expression of a rat V1a arginine vasopressin receptor. Nature 356: 523-6 [PMID:1560825]

174. Morin D, Ala Y, Sabatier N, Cotte N, Hendy G, Vargas R, Déchaux M, Antignac C, Hibert M, Bichet D and Barberis C. (1998) Functional study of two V2 vasopressin mutant receptors related to NDI. P322S and P322H. Adv Exp Med Biol 449: 391-393 [PMID:10026830] 
175. Moses AM, Sangani G and Miller JL. (1995) Proposed cause of marked vasopressin resistance in a female with an X-linked recessive V2 receptor abnormality. J. Clin. Endocrinol. Metab. 80: 1184-6 [PMID:7714087]

176. Mouillac B, Chini B, Balestre MN, Elands J, Trumpp-Kallmeyer S, Hoflack J, Hibert M, Jard S and Barberis C. (1995) The binding site of neuropeptide vasopressin V1a receptor. Evidence for a major localization within transmembrane regions. J. Biol. Chem. 270: 25771-7 [PMID:7592759]

177. Mune T, Murase H, Yamakita N, Fukuda T, Murayama M, Miura A, Suwa T, Hanafusa J, Daido H and Morita $\mathrm{H}$ et al.. (2002) Eutopic overexpression of vasopressin v1a receptor in adrenocorticotropinindependent macronodular adrenal hyperplasia. J. Clin. Endocrinol. Metab. 87: 5706-13 [PMID:12466375]

178. Murasawa S, Matsubara H, Kizima K, Maruyama K, Mori Y and Inada M. (1995) Glucocorticoids regulate V1a vasopressin receptor expression by increasing mRNA stability in vascular smooth muscle cells. Hypertension 26: 665-9 [PMID:7558228]

179. Naitoh M, Burrell LM, Risvanis J, Aldred KL, Rockell MD, Johnston Cl and Phillips PA. (1997) Modulation of genetic hypertension by short-term AVP V1A or V2 receptor antagonism in young SHR. Am. J. Physiol. 272: F229-34 [PMID:9124400]

180. Nakamura S, Hirano T, Tsujimae K, Aoyama M, Kondo K, Yamamura Y, Mori T and Tominaga M. (2000) Antidiuretic effects of a nonpeptide vasopressin V(2)-receptor agonist, OPC-51803, administered orally to rats. J. Pharmacol. Exp. Ther. 295: 1005-11 [PMID:11082435]

181. Nakamura S, Yamamura Y, Itoh S, Hirano T, Tsujimae K, Aoyama M, Kondo K, Ogawa H, Shinohara T and Kan K et al.. (2000) Characterization of a novel nonpeptide vasopressin V(2)-agonist, OPC-51803, in cells transfected human vasopressin receptor subtypes. Br. J. Pharmacol. 129: 1700-6 [PMID:10780976]

182. Nakanishi K, Mattson DL, Gross V, Roman RJ and Cowley Jr AW. (1995) Control of renal medullary blood flow by vasopressin V1 and V2 receptors. Am. J. Physiol. 269: R193-200 [PMID:7631893]

183. Neumann ID, Wigger A, Torner L, Holsboer F and Landgraf R. (2000) Brain oxytocin inhibits basal and stress-induced activity of the hypothalamo-pituitary-adrenal axis in male and female rats: partial action within the paraventricular nucleus. J. Neuroendocrinol. 12: 235-43 [PMID:10718919]

184. Nishimori K, Young LJ, Guo Q, Wang Z, Insel TR and Matzuk MM. (1996) Oxytocin is required for nursing but is not essential for parturition or reproductive behavior. Proc. Natl. Acad. Sci. U.S.A. 93: 11699-704 [PMID:8876199]

185. Nonoguchi H, Owada A, Kobayashi N, Takayama M, Terada Y, Koike J, Ujiie K, Marumo F, Sakai T and Tomita K. (1995) Immunohistochemical localization of V2 vasopressin receptor along the nephron and functional role of luminal V2 receptor in terminal inner medullary collecting ducts. J Clin Invest 96: 17681778 [PMID:7560068]

186. O'Carroll AM, Howell GM, Roberts EM and Lolait SJ. (2008) Vasopressin potentiates corticotropinreleasing hormone-induced insulin release from mouse pancreatic beta-cells. J. Endocrinol. 197: 231-9 [PMID:18434353]

187. O'Connor PM and Cowley Jr AW. (2007) Vasopressin-induced nitric oxide production in rat inner medullary collecting duct is dependent on $\mathrm{V} 2$ receptor activation of the phosphoinositide pathway. Am. J. Physiol. Renal Physiol. 293: F526-32 [PMID:17507604]

188. Oikawa R, Nasa Y, Ishii R, Kuwaki T, Tanoue A, Tsujimoto G and Takeo S. (2007) Vasopressin V1A receptor enhances baroreflex via the central component of the reflex arc. Eur. J. Pharmacol. 558: 144-50 [PMID:17224142]

189. Oksche A, Leder G, Valet S, Platzer M, Hasse K, Geist S, Krause G, Rosenthal A and Rosenthal W. (2002) Variant amino acids in the extracellular loops of murine and human vasopressin V2 receptors account for differences in cell surface expression and ligand affinity. Mol. Endocrinol. 16: 799-813 [PMID:11923476]

190. Oksche A, Möller A, Dickson J, Rosendahl W, Rascher W, Bichet DG and Rosenthal W. (1996) Two novel mutations in the aquaporin-2 and the vasopressin V2 receptor genes in patients with congenital nephrogenic diabetes insipidus. Hum. Genet. 98: 587-9 [PMID:8882880]

191. Oksche A, Schülein R, Rutz C, Liebenhoff U, Dickson J, Müller H, Birnbaumer M and Rosenthal W. (1996) 
Vasopressin V2 receptor mutants that cause X-linked nephrogenic diabetes insipidus: analysis of expression, processing, and function. Mol. Pharmacol. 50: 820-8 [PMID:8863826]

192. Oliver $G$ and Schäfer EA. (1895) On the Physiological Action of Extracts of Pituitary Body and certain other Glandular Organs: Preliminary Communication. J. Physiol. (Lond.) 18: 277-9 [PMID:16992253]

193. Olson BR, Drutarosky MD, Chow MS, Hruby VJ, Stricker EM and Verbalis JG. (1991) Oxytocin and an oxytocin agonist administered centrally decrease food intake in rats. Peptides 12: 113-8 [PMID:1646995]

194. Onaka T, Ikeda K, Yamashita T and Honda K. (2003) Facilitative role of endogenous oxytocin in noradrenaline release in the rat supraoptic nucleus. Eur. J. Neurosci. 18: 3018-26 [PMID:14656297]

195. Orcel H, Albizu L, Perkovska S, Durroux T, Mendre C, Ansanay H, Mouillac B and Rabié A. (2009) Differential coupling of the vasopressin $\mathrm{V} 1 \mathrm{~b}$ receptor through compartmentalization within the plasma membrane. Mol. Pharmacol. 75: 637-47 [PMID:19047484]

196. Oshikawa S, Tanoue A, Koshimizu TA, Kitagawa Y and Tsujimoto G. (2004) Vasopressin stimulates insulin release from islet cells through $\mathrm{V} 1 \mathrm{~b}$ receptors: a combined pharmacological/knockout approach. Mol. Pharmacol. 65: 623-9 [PMID:14978240]

197. Ostrowski NL. (1998) Oxytocin receptor mRNA expression in rat brain: implications for behavioral integration and reproductive success. Psychoneuroendocrinology 23: 989-1004 [PMID:9924748]

198. Ostrowski NL and Lolait SJ. (1995) Oxytocin receptor gene expression in female rat kidney. The effect of estrogen. Adv. Exp. Med. Biol. 395: 329-40 [PMID:8713983]

199. Ostrowski NL, Lolait SJ and Young 3rd WS. (1994) Cellular localization of vasopressin V1a receptor messenger ribonucleic acid in adult male rat brain, pineal, and brain vasculature. Endocrinology 135: 151128 [PMID:7925112]

200. Ostrowski NL, Young 3rd WS, Knepper MA and Lolait SJ. (1993) Expression of vasopressin V1a and V2 receptor messenger ribonucleic acid in the liver and kidney of embryonic, developing, and adult rats. Endocrinology 133: 1849-59 [PMID:8404628]

201. Pagani JH, Zhao M, Cui Z, Avram SK, Caruana DA, Dudek SM and Young WS. (2015) Role of the vasopressin $1 \mathrm{~b}$ receptor in rodent aggressive behavior and synaptic plasticity in hippocampal area CA2. Mol. Psychiatry 20: 490-9 [PMID:24863146]

202. Pan Y, Metzenberg A, Das S, Jing B and Gitschier J. (1992) Mutations in the V2 vasopressin receptor gene are associated with $X$-linked nephrogenic diabetes insipidus. Nat. Genet. 2: 103-6 [PMID:1303257]

203. Pasel K, Schulz A, Timmermann K, Linnemann K, Hoeltzenbein M, Jääskeläinen J, Grüters A, Filler G and Schöneberg T. (2000) Functional characterization of the molecular defects causing nephrogenic diabetes insipidus in eight families. J. Clin. Endocrinol. Metab. 85: 1703-10 [PMID:10770218]

204. Pedersen CA and Prange AJ. (1979) Induction of maternal behavior in virgin rats after intracerebroventricular administration of oxytocin. Proc. Natl. Acad. Sci. U.S.A. 76: 6661-5 [PMID:293752]

205. Pena A, Murat B, Trueba M, Ventura MA, Wo NC, Szeto HH, Cheng LL, Stoev S, Guillon G and Manning M. (2007) Design and synthesis of the first selective agonists for the rat vasopressin $V(1 b)$ receptor: based on modifications of deamino-[Cys1]arginine vasopressin at positions 4 and 8. J Med Chem 50: 835-847 [PMID:17300166]

206. Pettibone DJ, Woyden CJ and Totaro JA. (1990) Identification of functional oxytocin receptors in lactating rat mammary gland in vitro. Eur. J. Pharmacol. 188: 235-41 [PMID:2163875]

207. Phalipou S, Cotte N, Carnazzi E, Seyer R, Mahe E, Jard S, Barberis C and Mouillac B. (1997) Mapping peptide-binding domains of the human $\mathrm{V} 1 \mathrm{a}$ vasopressin receptor with a photoactivatable linear peptide antagonist. J. Biol. Chem. 272: 26536-44 [PMID:9334232]

208. Pierzynski P, Lemancewicz A, Reinheimer T, Akerlund M and Laudanski T. (2004) Inhibitory effect of barusiban and atosiban on oxytocin-induced contractions of myometrium from preterm and term pregnant women. J. Soc. Gynecol. Investig. 11: 384-7 [PMID:15350251]

209. Promeneur D, Kwon TH, Frøkiaer J, Knepper MA and Nielsen S. (2000) Vasopressin V(2)-receptordependent regulation of AQP2 expression in Brattleboro rats. Am. J. Physiol. Renal Physiol. 279: F370-82 [PMID:10919858]

210. Quattropani A, Dorbais J, Covini D, Pittet PA, Colovray V, Thomas RJ, Coxhead R, Halazy S, Scheer A 
and Missotten $\mathrm{M}$ et al.. (2005) Discovery and development of a new class of potent, selective, orally active oxytocin receptor antagonists. J. Med. Chem. 48: 7882-905 [PMID:16302826]

211. Rabadan-Diehl C, Lolait SJ and Aguilera G. (1995) Regulation of pituitary vasopressin V1b receptor mRNA during stress in the rat. J. Neuroendocrinol. 7: 903-10 [PMID:8745267]

212. Rahmeh R, Damian M, Cottet M, Orcel H, Mendre C, Durroux T, Sharma KS, Durand G, Pucci B and Trinquet $E$ et al.. (2012) Structural insights into biased $G$ protein-coupled receptor signaling revealed by fluorescence spectroscopy. Proc. Natl. Acad. Sci. U.S.A. 109: 6733-8 [PMID:22493271]

213. Randolph GW and Fuchs AR. (1989) Pulsatile administration enhances the effect and reduces the dose of oxytocin required for induction of labor. Am J Perinato/ 6: 159-66 [PMID:2712912]

214. Rao VV, Löffler C, Battey J and Hansmann I. (1992) The human gene for oxytocin-neurophysin I (OXT) is physically mapped to chromosome 20 p13 by in situ hybridization. Cytogenet. Cell Genet. 61: 271-3 [PMID:1486803]

215. Ratni H, Rogers-Evans M, Bissantz C, Grundschober C, Moreau JL, Schuler F, Fischer H, Alvarez Sanchez R and Schnider P. (2015) Discovery of highly selective brain-penetrant vasopressin 1a antagonists for the potential treatment of autism via a chemogenomic and scaffold hopping approach. $J$. Med. Chem. 58: 2275-89 [PMID:25654260]

216. Rauen K, Trabold R, Brem C, Terpolilli NA and Plesnila N. (2013) Arginine vasopressin V1a receptordeficient mice have reduced brain edema and secondary brain damage following traumatic brain injury. $J$. Neurotrauma 30: 1442-8 [PMID:23441636]

217. René $P$, Lenne F, Ventura MA, Bertagna $X$ and de Keyzer $Y$. (2000) Nucleotide sequence and structural organization of the human vasopressin pituitary receptor (V3) gene. Gene 241: 57-64 [PMID:10607899]

218. Reversi A, Rimoldi V, Marrocco T, Cassoni P, Bussolati G, Parenti M and Chini B. (2005) The oxytocin receptor antagonist atosiban inhibits cell growth via a "biased agonist" mechanism. J. Biol. Chem. 280: 16311-8 [PMID:15705593]

219. Robben JH, Knoers NV and Deen PM. (2006) Cell biological aspects of the vasopressin type-2 receptor and aquaporin 2 water channel in nephrogenic diabetes insipidus. Am. J. Physiol. Renal Physiol. 291: F257-70 [PMID:16825342]

220. Robinson DA, Wei F, Wang GD, Li P, Kim SJ, Vogt SK, Muglia LJ and Zhuo M. (2002) Oxytocin mediates stress-induced analgesia in adult mice. J Physiol 540: 593-606 [PMID:11956346]

221. Rocha JL, Friedman E, Boson W, Moreira A, Figueiredo B, Liberman B, de Lacerda L, Sandrini R, Graf H and Martins $S$ et al.. (1999) Molecular analyses of the vasopressin type 2 receptor and aquaporin-2 genes in Brazilian kindreds with nephrogenic diabetes insipidus. Hum. Mutat. 14: 233-9 [PMID:10477431]

222. Rosenthal SM, Feldman BJ, Vargas GA and Gitelman SE. (2006) Nephrogenic syndrome of inappropriate antidiuresis (NSIAD): a paradigm for activating mutations causing endocrine dysfunction. Pediatr Endocrinol Rev 4 Suppl 1: 66-70 [PMID:17261972]

223. Rozen F, Russo C, Banville D and Zingg HH. (1995) Structure, characterization, and expression of the rat oxytocin receptor gene. Proc. Natl. Acad. Sci. U.S.A. 92: 200-4 [PMID:7816817]

224. Saito M, Sugimoto T, Tahara A and Kawashima H. (1995) Molecular cloning and characterization of rat V1b vasopressin receptor: evidence for its expression in extra-pituitary tissues. Biochem. Biophys. Res. Commun. 212: 751-7 [PMID:7626108]

225. Saito M, Tahara A and Sugimoto T. (1997) 1-desamino-8-D-arginine vasopressin (DDAVP) as an agonist on V1b vasopressin receptor. Biochem Pharmacol 53: 1711-1717 [PMID:9264324]

226. Sato K, Fukuno H, Taniguchi T, Sawada S, Fukui T and Kinoshita M. (1999) A novel mutation in the vasopressin V2 receptor gene in a woman with congenital nephrogenic diabetes insipidus. Intern. Med. 38: 808-12 [PMID:10526945]

227. Schlosser SF, Almeida OF, Patchev VK, Yassouridis A and Elands J. (1994) Oxytocin-stimulated release of adrenocorticotropin from the rat pituitary is mediated by arginine vasopressin receptors of the $\mathrm{V} 1 \mathrm{~b}$ type. Endocrinology 135: 2058-63 [PMID:7956927]

228. Schmale H, Heinsohn S and Richter D. (1983) Structural organization of the rat gene for the arginine vasopressin-neurophysin precursor. EMBO J. 2: 763-7 [PMID:6315416] 
229. Schwartz J, Derdowska I, Sobocinska M and Kupryszewski G. (1991) A potent new synthetic analog of vasopressin with relative agonist specificity for the pituitary. Endocrinology 129: 1107-9 [PMID:1649739]

230. Schöneberg T, Kostenis E, Liu J, Gudermann T and Wess J. (1998) Molecular aspects of vasopressin receptor function. Adv. Exp. Med. Biol. 449: 347-58 [PMID:10026824]

231. Schülein R, Zühlke K, Krause $G$ and Rosenthal W. (2001) Functional rescue of the nephrogenic diabetes insipidus-causing vasopressin V2 receptor mutants $\mathrm{G} 185 \mathrm{C}$ and $\mathrm{R} 202 \mathrm{C}$ by a second site suppressor mutation. J. Biol. Chem. 276: 8384-92 [PMID:11116139]

232. Seibold A, Brabet $P$, Rosenthal $W$ and Birnbaumer M. (1992) Structure and chromosomal localization of the human antidiuretic hormone receptor gene. Am. J. Hum. Genet. 51: 1078-83 [PMID:1415251]

233. Serradeil-Le Gal C, Lacour C, Valette G, Garcia G, Foulon L, Galindo G, Bankir L, Pouzet B, Guillon G and Barberis C et al.. (1996) Characterization of SR 121463A, a highly potent and selective, orally active vasopressin V2 receptor antagonist. J. Clin. Invest. 98: 2729-38 [PMID:8981918]

234. Serradeil-Le Gal C, Raufaste D, Double-Cazanave E, Guillon G, Garcia C, Pascal M and Maffrand JP. (2000) Binding properties of a selective tritiated vasopressin V2 receptor antagonist, [H]-SR 121463. Kidney Int. 58: 1613-22 [PMID:11012895]

235. Serradeil-Le Gal C, Raufaste D, Marty E, Garcia C, Maffrand JP and Le Fur G. (1994) Binding of [3H] SR 49059, a potent nonpeptide vasopressin V1a antagonist, to rat and human liver membranes. Biochem. Biophys. Res. Commun. 199: 353-60 [PMID:8123034]

236. Serradeil-Le Gal C, Valette G, Foulon L, Germain G, Advenier C, Naline E, Bardou M, Martinolle J-P, Pouzet B, Raufaste D, Garcia C, Double-Cazenave E, Pauly M, Pascal M, Barbier A, Scatton B, Maffrand J-P and Le Fur G. (2004) SSR126768A (4-Chloro-3-[(3R)-(+)-5-chloro-1-(2,4-dimethoxybenzyl)-3-methyl2oxo-2,3-dihydro-1H-indol-3-yl]-N-ethyl-N-(3-pyridylmethyl)-benzamidine, hydrochloride): a new selective and orally active oxytocin receptor antagonist for the prevention of preterm labor. $J$ Pharmacol Exp Therap 309: 414-424 [PMID:14722330]

237. Serradeil-Le Gal C, Wagnon J, Garcia C, Lacour C, Guiraudou P, Christophe B, Villanova G, Nisato D, Maffrand JP and Le Fur G et al.. (1993) Biochemical and pharmacological properties of SR49059, a new potent nonpeptide antagonist of rat and human vasopressin V1a receptor. J Clin Invest 92: 224-231 [PMID:8392086]

238. Serradeil-Le Gal C, Wagnon J, Simiand J, Griebel G, Lacour C, Guillon G, Barberis C, Brossard G, Soubrie P, Nisato D, Pascal M, Pruss R, Scatton B, Maffrand JP and Le Fur G. (2002) Characterization of (2S,4R)1-[5-chloro-1-[(2,4-dimethoxyphenyl)sulfonyl]-3-(2-methoxy-phenyl)-2-oxo-2,3-dihydro-1H-indol-3-yl]-4hydroxy-N,N-dimethyl-2-pyrrolidine carboxamide (SSR149415), a selective and orally active vasopressin V1b receptor antagonist. J Pharmacol Exp Ther 300: 1122-1130 [PMID:11861823]

239. Shi W, Cui N, Shi Y, Zhang X, Yang Y and Jiang C. (2007) Arginine vasopressin inhibits Kir6.1/SUR2B channel and constricts the mesenteric artery via $\mathrm{V} 1$ a receptor and protein kinase C. Am. J. Physiol. Regul. Integr. Comp. Physiol. 293: R191-9 [PMID:17428891]

240. Sjöquist M, Huang W, Jacobsson E, Skøtt O, Stricker EM and Sved AF. (1999) Sodium excretion and renin secretion after continuous versus pulsatile infusion of oxytocin in rats. Endocrinology 140: 2814-8 [PMID:10342872]

241. Soloff MS, Jeng YJ, Copland JA, Strakova Z and Hoare S. (2000) Signal pathways mediating oxytocin stimulation of prostaglandin synthesis in select target cells. Exp. Physiol. 85 Spec No: 51S-58S [PMID:10795906]

242. Soloff MS and Wieder MH. (1983) Oxytocin receptors in rat involuting mammary gland.Can. J. Biochem. Cell Biol. 61: 631-5 [PMID:6313159]

243. Stewart LQ, Roper JA, Young 3rd WS, O'Carroll AM and Lolait SJ. (2008) Pituitary-adrenal response to acute and repeated mild restraint, forced swim and change in environment stress in arginine vasopressin receptor 1b knockout mice. J. Neuroendocrinol. 20: 597-605 [PMID:18363802]

244. Stewart LQ, Roper JA, Young 3rd WS, O'Carroll AM and Lolait SJ. (2008) The role of the arginine vasopressin Avp1b receptor in the acute neuroendocrine action of antidepressants.

Psychoneuroendocrinology 33: 405-15 [PMID:18243568] 
245. Strakova Z, Copland JA, Lolait SJ and Soloff MS. (1998) ERK2 mediates oxytocin-stimulated PGE2 synthesis. Am. J. Physiol. 274: E634-41 [PMID:9575824]

246. Strakova $Z$ and Soloff MS. (1997) Coupling of oxytocin receptor to G proteins in rat myometrium during labor: Gi receptor interaction. Am. J. Physiol. 272: E870-6 [PMID:9176188]

247. Sugimoto T, Saito M, Mochizuki S, Watanabe Y, Hashimoto S and Kawashima H. (1994) Molecular cloning and functional expression of a cDNA encoding the human $\mathrm{V} 1 \mathrm{~b}$ vasopressin receptor. J. Biol. Chem. 269: 27088-92 [PMID:7929452]

248. Szalai C, Triga D and Czinner A. (1998) C112R, W323S, N317K mutations in the vasopressin V2 receptor gene in patients with nephrogenic diabetes insipidus. Mutations in brief no. 165. Online. Hum. Mutat. 12: 137-8 [PMID:10694923]

249. Szot $P$, Bale TL and Dorsa DM. (1994) Distribution of messenger RNA for the vasopressin V1a receptor in the CNS of male and female rats. Brain Res Mol Brain Res24: 1-10 [PMID:7968346]

250. Tachikawa K, Yokoi H, Nagasaki H, Arima H, Murase T, Sugimura Y, Miura Y, Hirabayashi M and Oiso Y. (2003) Altered cardiovascular regulation in arginine vasopressin-overexpressing transgenic rat. Am. J. Physiol. Endocrinol. Metab. 285: E1161-6 [PMID:12915399]

251. Tahara A, Saito M, Sugimoto T, Tomura Y, Wada K, Kusayama T, Tsukada J, Ishii N, Yatsu T and Uchida $W$ et al.. (1999) AVP-induced mitogenic responses of Chinese hamster ovary cells expressing human V1A or V1B receptors. Pflugers Arch. 437: 219-26 [PMID:9929562]

252. Tahara A, Saito M, Sugimoto T, Tomura Y, Wada K, Kusayama T, Tsukada J, Ishii N, Yatsu T and Uchida W et al.. (1998) Pharmacological characterization of the human vasopressin receptor subtypes stably expressed in Chinese hamster ovary cells. Br. J. Pharmacol. 125: 1463-70 [PMID:9884074]

253. Tahara A, Saito M, Sugimoto T, Tomura Y, Wada K, Kusayama T, Tsukada J, Ishii N, Yatsu T and Uchida W et al.. (1998) Pharmacological characterization of YM087, a potent, nonpeptide human vasopressin V1A and V2 receptor antagonist. Naunyn Schmiedebergs Arch. Pharmacol. 357: 63-9 [PMID:9459574]

254. Tahara A, Tomura Y, Wada K, Kusayama T, Tsukada J, Ishii N, Yatsu T, Uchida W and Tanaka A. (1998) Characterization of vasopressin receptor in rat lung. Neuropeptides 32: 281-6 [PMID:10189064]

255. Tahara A, Tsukada J, Tomura Y, Kusayama T, Wada K, Ishii N, Taniguchi N, Suzuki T, Yatsu T and Uchida W et al.. (2005) Effects of YM218, a nonpeptide vasopressin V1A receptor-selective antagonist, on human vasopressin and oxytocin receptors. Pharmacol. Res. 51: 275-81 [PMID:15661579]

256. Tajima T, Nakae J, Takekoshi Y, Takahashi Y, Yuri K, Nagashima T and Fujieda K. (1996) Three novel AVPR2 mutations in three Japanese families with X-linked nephrogenic diabetes insipidus. Pediatr. Res. 39: 522-6 [PMID:8929875]

257. Takayanagi Y, Yoshida M, Bielsky IF, Ross HE, Kawamata M, Onaka T, Yanagisawa T, Kimura T, Matzuk $\mathrm{MM}$ and Young LJ et al.. (2005) Pervasive social deficits, but normal parturition, in oxytocin receptordeficient mice. Proc. Natl. Acad. Sci. U.S.A. 102: 16096-101 [PMID:16249339]

258. Tanoue A, Ito S, Honda K, Oshikawa S, Kitagawa Y, Koshimizu TA, Mori T and Tsujimoto G. (2004) The vasopressin $\mathrm{V} 1 \mathrm{~b}$ receptor critically regulates hypothalamic-pituitary-adrenal axis activity under both stress and resting conditions. J. Clin. Invest. 113: $302-9$ [PMID:14722621]

259. Terada Y, Tomita K, Nonoguchi H, Yang T and Marumo F. (1993) Different localization and regulation of two types of vasopressin receptor messenger RNA in microdissected rat nephron segments using reverse transcription polymerase chain reaction. J. Clin. Invest. 92: 2339-45 [PMID:8227349]

260. Terrillon S, Barberis $C$ and Bouvier M. (2004) Heterodimerization of V1a and V2 vasopressin receptors determines the interaction with beta-arrestin and their trafficking patterns. Proc. Natl. Acad. Sci. U.S.A. 101: 1548-53 [PMID:14757828]

261. Terrillon S, Durroux T, Mouillac B, Breit A, Ayoub MA, Taulan M, Jockers R, Barberis C and Bouvier M. (2003) Oxytocin and vasopressin V1a and V2 receptors form constitutive homo- and heterodimers during biosynthesis. Mol. Endocrinol. 17: 677-91 [PMID:12554793]

262. Thibonnier M, Auzan C, Madhun Z, Wilkins P, Berti-Mattera L and Clauser E. (1994) Molecular cloning, sequencing, and functional expression of a cDNA encoding the human V1a vasopressin receptor. J. Biol. Chem. 269: 3304-10 [PMID:8106369] 
263. Thibonnier M, Conarty DM, Preston JA, Plesnicher CL, Dweik RA and Erzurum SC. (1999) Human vascular endothelial cells express oxytocin receptors. Endocrinology 140: 1301-9 [PMID:10067857]

264. Thibonnier M, Graves MK, Wagner MS, Auzan C, Clauser E and Willard HF. (1996) Structure, sequence, expression, and chromosomal localization of the human V1a vasopressin receptor gene. Genomics 31: 327-34 [PMID:8838314]

265. Thibonnier M, Preston JA, Dulin N, Wilkins PL, Berti-Mattera LN and Mattera R. (1997) The human V3 pituitary vasopressin receptor: ligand binding profile and density-dependent signaling pathways. Endocrinology 138: 4109-22 [PMID:9322919]

266. Thornton S, Baldwin PJ, Harris PA, Harding F, Davison JM, Baylis PH, Timmons PM and Wathes DC. (2002) The role of arginine vasopressin in human labour: functional studies, fetal production and localisation of V1a receptor mRNA. BJOG 109: 57-62 [PMID:11843375]

267. Trejter M, Carraro G, Rucinski M, Hochol A, Rebuffat P, Nussdorfer GG and Malendowicz LK. (2005) Arginin-vasopressin regulates proliferative activity of the regenerating rat adrenal cortex. Int $J$ Mol Med 15: 993-997 [PMID:15870905]

268. Tribollet E, Charpak S, Schmidt A, Dubois-Dauphin M and Dreifuss JJ. (1989) Appearance and transient expression of oxytocin receptors in fetal, infant, and peripubertal rat brain studied by autoradiography and electrophysiology. J. Neurosci. 9: 1764-73 [PMID:2542479]

269. Tsukada J, Tahara A, Tomura Y, Wada Ki, Kusayama T, Ishii N, Yatsu T, Uchida W, Taniguchi N and Tanaka A. (2001) Effects of YM471, a nonpeptide AVP V(1A) and V(2) receptor antagonist, on human AVP receptor subtypes expressed in $\mathrm{CHO}$ cells and oxytocin receptors in human uterine smooth muscle cells. Br. J. Pharmacol. 133: 746-54 [PMID:11429400]

270. Tsukaguchi H, Matsubara H, Aritaki S, Kimura T, Abe S and Inada M. (1993) Two novel mutations in the vasopressin V2 receptor gene in unrelated Japanese kindreds with nephrogenic diabetes insipidus. Biochem. Biophys. Res. Commun. 197: 1000-10 [PMID:8267567]

271. Tsukaguchi $H$, Matsubara $H$ and Inada M. (1995) Expression studies of two vasopressin V2 receptor gene mutations, R202C and 804insG, in nephrogenic diabetes insipidus. Kidney Int. 48: 554-62 [PMID:7564126]

272. Vaccari C, Lolait SJ and Ostrowski NL. (1998) Comparative distribution of vasopressin V1b and oxytocin receptor messenger ribonucleic acids in brain. Endocrinology 139: 5015-33 [PMID:9832441]

273. Vale W, Vaughan J, Smith M, Yamamoto G, Rivier J and Rivier C. (1983) Effects of synthetic ovine corticotropin-releasing factor, glucocorticoids, catecholamines, neurohypophysial peptides, and other substances on cultured corticotropic cells. Endocrinology 113: 1121-31 [PMID:6307665]

274. van West D, Del-Favero J, Aulchenko Y, Oswald P, Souery D, Forsgren T, Sluijs S, Bel-Kacem S, Adolfsson R and Mendlewicz J et al.. (2004) A major SNP haplotype of the arginine vasopressin 1B receptor protects against recurrent major depression. Mol. Psychiatry 9: 287-92 [PMID:15094789]

275. van West D, Del-Favero J, Deboutte D, Van Broeckhoven C and Claes S. (2009) Arginine vasopressin receptor gene-based single-nucleotide polymorphism analysis in attention deficit hyperactivity disorder. Psychiatr. Genet. 19: 102-3 [PMID:19668115]

276. Ventura MA, René P, de Keyzer Y, Bertagna X and Clauser E. (1999) Gene and cDNA cloning and characterization of the mouse V3/V1b pituitary vasopressin receptor. J. Mol. Endocrinol. 22: 251-60 [PMID:10343284]

277. Vezzosi D, Cartier D, Régnier C, Otal P, Bennet A, Parmentier F, Plantavid M, Lacroix A, Lefebvre H and Caron P. (2007) Familial adrenocorticotropin-independent macronodular adrenal hyperplasia with aberrant serotonin and vasopressin adrenal receptors. Eur. J. Endocrinol. 156: 21-31 [PMID:17218722]

278. Vignozzi L, Filippi S, Luconi M, Morelli A, Mancina R, Marini M, Vannelli GB, Granchi S, Orlando C and Gelmini S et al.. (2004) Oxytocin receptor is expressed in the penis and mediates an estrogen-dependent smooth muscle contractility. Endocrinology 145: 1823-34 [PMID:14691010]

279. Vignozzi L, Vannelli GB, Morelli A, Mancina R, Marini M, Ferruzzi P, Crescioli C, Luconi M, Donati S and Fisher $A D$ et al.. (2005) Identification, characterization and biological activity of oxytocin receptor in the developing human penis. Mol. Hum. Reprod. 11: 99-106 [PMID:15591449]

280. Weig HJ, Laugwitz KL, Moretti A, Kronsbein K, Städele C, Brüning S, Seyfarth M, Brill T, Schömig A and 
Ungerer M. (2000) Enhanced cardiac contractility after gene transfer of V2 vasopressin receptors In vivo by ultrasound-guided injection or transcoronary delivery. Circulation 101: 1578-85 [PMID:10747352]

281. Wersinger SR, Caldwell HK, Christiansen M and Young 3rd WS. (2007) Disruption of the vasopressin 1b receptor gene impairs the attack component of aggressive behavior in mice. Genes Brain Behav. 6: 65360 [PMID:17284170]

282. Wersinger SR, Caldwell HK, Martinez L, Gold P, Hu SB and Young 3rd WS. (2007) Vasopressin 1a receptor knockout mice have a subtle olfactory deficit but normal aggression. Genes Brain Behav. 6: 54051 [PMID:17083331]

283. Wersinger SR, Ginns El, O'Carroll AM, Lolait SJ and Young 3rd WS. (2002) Vasopressin V1b receptor knockout reduces aggressive behavior in male mice. Mol. Psychiatry 7: 975-84 [PMID:12399951]

284. Wersinger SR, Temple JL, Caldwell HK and Young 3rd WS. (2008) Inactivation of the oxytocin and the vasopressin (Avp) 1b receptor genes, but not the Avp 1a receptor gene, differentially impairs the Bruce effect in laboratory mice (Mus musculus). Endocrinology 149: 116-21 [PMID:17947352]

285. Wheatley M, Simms J, Hawtin SR, Wesley VJ, Wootten D, Conner M, Lawson Z, Conner AC, Baker A and Cashmore Y et al.. (2007) Extracellular loops and ligand binding to a subfamily of Family A G-proteincoupled receptors. Biochem. Soc. Trans. 35: 717-20 [PMID:17635132]

286. Wildin RS, Cogdell DE and Valadez V. (1998) AVPR2 variants and V2 vasopressin receptor function in nephrogenic diabetes insipidus. Kidney Int 54: 1909-1922 [PMID:9853256]

287. Wilson RJ, Allen MJ, Nandi M, Giles H and Thornton S. (2001) Spontaneous contractions of myometrium from humans, non-human primate and rodents are sensitive to selective oxytocin receptor antagonism in vitro. BJOG 108: 960-6 [PMID:11563467]

288. Windle RJ, Shanks N, Lightman SL and Ingram CD. (1997) Central oxytocin administration reduces stressinduced corticosterone release and anxiety behavior in rats. Endocrinology 138: 2829-34 [PMID:9202224]

289. Winslow JT, Hastings N, Carter CS, Harbaugh CR and Insel TR. (1993) A role for central vasopressin in pair bonding in monogamous prairie voles. Nature 365: 545-8 [PMID:8413608]

290. Yamaguchi Y, Suzuki T, Mizoro Y, Kori H, Okada K, Chen Y, Fustin JM, Yamazaki F, Mizuguchi N and Zhang J et al.. (2013) Mice genetically deficient in vasopressin V1a and V1b receptors are resistant to jet lag. Science 342: 85-90 [PMID:24092737]

291. Yamamura Y, Nakamura S, Itoh S, Hirano T, Onogawa T, Yamashita T, Yamada Y, Tsujimae K, Aoyama $\mathrm{M}$ and Kotosai K et al.. (1998) OPC-41061, a highly potent human vasopressin V2-receptor antagonist: pharmacological profile and aquaretic effect by single and multiple oral dosing in rats. J. Pharmacol. Exp. Ther. 287: 860-7 [PMID:9864265]

292. Yamamura Y, Ogawa H, Yamashita H, Chihara T, Miyamoto H, Nakamura S, Onogawa T, Yamashita T, Hosokawa T and Mori T. (1992) Characterization of a novel aquaretic agent, OPC-31260, as an orally effective, nonpeptide vasopressin V2 receptor antagonist. Br. J. Pharmacol. 105: 787-91 [PMID:1387020]

293. Yang J, Yang Y, Chen JM, Wang G, Xu HT, Liu WY and Lin BC. (2007) Periaqueductal gray knockdown of V2, not V1a and V1b receptor influences nociception in the rat. yj6676@yahoo.com. Neurosci. Res. 57: 104-11 [PMID:17056144]

294. Yates FE, Russell SM, Dallman MF, Hodge GA, McCann SM and Dhariwal AP. (1971) Potentiation by vasopressin of corticotropin release induced by corticotropin-releasing factor. Endocrinology 88: 3-15 [PMID:4320769]

295. Yirmiya N, Rosenberg C, Levi S, Salomon S, Shulman C, Nemanov L, Dina C and Ebstein RP. (2006) Association between the arginine vasopressin 1a receptor (AVPR1a) gene and autism in a family-based study: mediation by socialization skills. Mol. Psychiatry 11: 488-94 [PMID:16520824]

296. Young 3rd WS, Shepard E, Amico J, Hennighausen L, Wagner KU, LaMarca ME, McKinney C and Ginns El. (1996) Deficiency in mouse oxytocin prevents milk ejection, but not fertility or parturition. $J$. Neuroendocrinol. 8: 847-53 [PMID:8933362]

297. Young LJ and Flanagan-Cato LM. (2012) Editorial comment: oxytocin, vasopressin and social behavior. Horm Behav 61: 227-9 [PMID:22443808]

298. Young LJ, Nilsen R, Waymire KG, MacGregor GR and Insel TR. (1999) Increased affiliative response to 
vasopressin in mice expressing the V1a receptor from a monogamous vole. Nature 400: 766-8 [PMID:10466725]

299. Young SF, Griffante C and Aguilera G. (2007) Dimerization between vasopressin V1b and corticotropin releasing hormone type 1 receptors. Cell. Mol. Neurobiol. 27: 439-61 [PMID:17318384]

300. Young WS, Li J, Wersinger SR and Palkovits M. (2006) The vasopressin $1 \mathrm{~b}$ receptor is prominent in the hippocampal area CA2 where it is unaffected by restraint stress or adrenalectomy. Neuroscience 143: 1031-9 [PMID:17027167]

301. Yun J, Schöneberg T, Liu J, Schulz A, Ecelbarger CA, Promeneur D, Nielsen S, Sheng H, Grinberg A and Deng $C$ et al.. (2000) Generation and phenotype of mice harboring a nonsense mutation in the V2 vasopressin receptor gene. J. Clin. Invest. 106: 1361-71 [PMID:11104789]

302. Zhang XH, Filippi S, Vignozzi L, Morelli A, Mancina R, Luconi M, Donati S, Marini M, Vannelli GB, Forti G and Maggi M. (2005) Identification, localization and functional in vitro and in vivo activity of oxytocin receptor in the rat penis. $J$ Endocrinol 184: 567-576 [PMID:15749815] 